DOI: https://doi.org/10.47405/mjssh.v6i8.978

\begin{tabular}{|c|c|}
\hline $5=$ & Malaysian Journal of Social Sciences and Humanities (MJSSH) \\
\hline Malaysian Journal of & Volume 6, Issue 8, August 2021 \\
\hline (MJ-sSH) & e-ISSN : 2504-8562 \\
\hline & $\begin{array}{l}\text { Journal home page: } \\
\text { www.msocialsciences.com }\end{array}$ \\
\hline
\end{tabular}

\title{
Persepsi Impak Industri Pelancongan terhadap Kualiti Hidup Komuniti Setempat di Batu Ferringhi, Pulau Pinang
}

\author{
Farah Husna Anwar¹, Mohammad Mujaheed Hassan'1, Azlina Mohd Khir ${ }^{1}$ \\ 1Jabatan Sains Kemasyarakatan dan Pembangunan, Fakulti Ekologi Manusia, Universiti Putra Malaysia (UPM) \\ Correspondence: Farah Husna Anwar (farahusna.anwar95@gmail.com)
}

\begin{abstract}
Abstrak
Industri pelancongan merupakan salah satu industri terpenting yang menyumbang kepada pertumbuhan dan pembangunan sesebuah negara dalam pelbagai aspek antaranya dari aspek ekonomi, sosial, budaya dan alam sekitar. Pertumbuhan dan pembangunan industri pelancongan dalam pelbagai aspek ini boleh memberi impak kepada kualiti hidup komuniti setempat sama ada dalam bentuk yang positif mahupun negatif. Sebuah kajian telah dijalankan bagi mengkaji persepsi impak industri pelancongan terhadap kualiti hidup komuniti setempat di Batu Ferringhi, Pulau Pinang. Batu Feringghi merupakan salah sebuah tempat pelancongan pesisiran pantai di negeri Pulau Pinang dan diklasifikasikan sebagai kawasan luar bandar oleh pihak berkuasa tempatan. Majoriti penduduknya adalah berbangsa Melayu. Seramai 383 komuniti setempat di Batu Ferringhi telah dipilih dan terlibat secara persampelan rawak mudah berlapis. Pengumpulan data dibuat dengan menggunakan set borang soal selidik yang diadaptasi dan diubahsuai daripada kajian-kajian lepas mengikut kesesuaian kajian yang dibuat. Instrumen kajian merangkumi soalan-soalan tentang latar belakang sosio-demografi komuniti setempat, persepsi impak industri pelancongan dan kualiti hidup komuniti setempat. Data dianalisis secara deskriptif dan inferensi iaitu Korelasi Pearson dan regresi. Hasil analisis kajian mendapati komuniti setempat memberi persepsi yang positif terhadap impak industri pelancongan terhadap kualiti hidup. Persepsi impak industri pelancongan oleh komuniti setempat menunjukkan terdapat hubungan yang signifikan dari aspek ekonomi $(r=0.518)$, sosial $(r=0.420)$, budaya $(r=0.629)$ dan alam sekitar $(r=0.627)$ dengan kualiti hidup. Keempat-empat persepsi impak tersebut menunjukkan 52\% kadar dalam mempengaruhi kualiti hidup komuniti setempat. Justeru itu, pertumbuhan dan pembangunan industri pelancongan di Batu Ferringhi perlu diteruskan kerana berupaya memberi impak yang positif kepada pembangunan kualiti hidup komuniti setempat di kawasan tersebut. Perancangan pertumbuhan dan pembangunan industri pelancongan perlu dirancang dengan mengambil kira perspektif kepentingan komuniti agar setiap pembangunan yang dibuat dapat meningkatkan pendapatan, menjana peluang pekerjaan baru dan menambah pelbagai kemudahan asas untuk meningkatkan kualiti hidup komuniti setempat. Selain itu, penglibatan dan penyertaan aktif komuniti setempat dalam pertumbuhan dan pembangunan industri pelancongan juga perlu diterapkan.
\end{abstract}

Kata kunci: persepsi, impak, industri pelancongan, kualiti hidup, pembangunan komuniti

\section{The Impact Perception of the Tourism Industry on the Quality of Life of the Local Community in Batu Ferringhi, Penang}

\author{
Abstract
}


The tourism industry is one of the most important industries that contribute to the growth and development of a country in various aspects, including economic, social, cultural and environmental. The growth and development of tourism institutions in various aspects can have an impact on the quality of life of the local community either in a positive or negative form. A research was conducted to study the impact perception of the tourism industry on the quality of life of the local community in Batu Ferringhi, Penang. Batu Feringghi is one of the coastal tourist spots in the state of Penang and it is classified as a rural area by local authorities. The majority of the residents are Malays. A total of 383 local communities in Batu Ferringhi were selected and involved in simple random layered sampling. The data was collected using the set of questionnaires adapted and modified from past studies according to the suitability of the research. The research instruments included questions about the sociodemographic background of the local community, the perception of the impact of the tourism industry and the quality of life of the local community. Data were analyzed descriptively and inferentially which are by Pearson Correlation and Regression. The results of the research analysis found that the local community had a positive perception of the impact of the tourism industry on the quality of life. The impact perception of the tourism industry by the local community showed significant relationship from the economic aspects $(r=0.518)$, social $(r=0.420)$, culture $(r=0.629)$ and the environment $(r=0.627)$ with quality of life. These four impact perceptions showed a $52 \%$ rate in influencing the quality of life of the local community. Hence, the growth and development of the tourism industry in Batu Ferringhi should continue as it has a positive impact on the development of the quality of life of the local communities in the area. Tourism inducement growth and development planning need to be planned taking into account the perspective of community interest so that every development made can increase local income, generate new job opportunities and add a variety of basic facilities to improve the quality of life of the local community. Besides that, active involvement and participation of the local community in the growth and development of the tourism industry should also be applied.

Keywords: perception, impact, tourism industry, quality of life, community development

\section{Pengenalan}

Sektor pelancongan memainkan peranan yang utama kepada sesebuah negara. Sumbangan sektor pelancongan ini dapat dilihat melalui pertumbuhan dan pembangunan ekonomi, kemajuan sosial serta pengagihan pendapatan dalam kalangan rakyat di sesebuah negara. Industri pelancongan merupakan industri terbesar di dunia dan dijangkakan akan tumbuh dengan lebih pesat pada masa hadapan. Pelancongan mempunyai pelbagai maksud berdasarkan perspektif dan pandangan seseorang yang terlibat dalam industri pelancongan. Mengikut Persatuan Pelancongan Sedunia (World Tourism Organization) pelancongan merupakan aktiviti pengembaraan seseorang individu ke suatu tempat, iaitu keluar daripada persekitaran asal yang menetap tidak lebih daripada satu tahun untuk tujuan rehat, perniagaan dan sebagainya. Industri pelancongan juga boleh ditakrifkan sebagai sebuah industri yang menyediakan infrastruktur, produk dan perkhidmatan bagi memudahkan perjalanan seseorang individu ke sesuatu tempat. Ini termasuklah tempahan perjalanan, pengangkutan, penginapan hotel, makanan, destinasi lawatan dan sebagainya.

Pelancongan dijadikan sebagai salah satu strategi pembangunan oleh kebanyakan negara yang sedang membangun. Ini adalah kerana pelancongan mendorong untuk bersaing dalam perdagangan antarabangsa, meluaskan pasaran untuk produk-produk keluaran tempatan seperti produk pertanian dan kraf tangan, membuka peluang pekerjaan serta suntikan wang baru ke dalam ekonomi yang mana sukar dicapai melalui strategi pembangunan yang lain (Wood, 1980). Penduduk tempatan juga berupaya menjadi aset pelancongan yang dapat menarik perhatian pelancong kerana keunikan budaya dan gaya hidup mereka. Tumpuan mula diberikan kepada apakah sebenarnya yang dihasilkan oleh pelancong, adakah boleh membawa kepada pembangunan komuniti setempat dan adakah pembangunan tersebut akan sentiasa dicapai secara berterusan?. Walhal pembangunan sebenarnya bukan sekadar diukur melalui pertumbuhan Keluaran Dalam Negara Kasar (KDNK) tetapi juga diukur dengan merujuk kepada kualiti hidup dan pembangunan sesebuah komuniti. 
Kualiti hidup di Malaysia merangkumi kemajuan diri, gaya hidup yang sihat, pencapaian dan kebebasan untuk memperoleh pengetahuan serta menikmati taraf hidup yang melebihi keperluan asas dan psikologi individu, mencapai tahap kesejahteraan sosial yang seiring dengan hasrat negara. Apabila sesebuah masyarakat beralih kepada suasana kehidupan yang pada amnya lebih baik, maka kualiti hidupnya dianggap telah meningkat. Mengikut World Health Organization (WHO), kualiti hidup didefinisikan sebagai anggapan individu mengenai posisi kehidupan mereka dalam konteks budaya dan sistem di mana berhubung rapat dengan matlamat, jangkaan, tahap dan beban.

Kualiti hidup diukur untuk pelbagai tujuan terutamanya berkaitan aspek sosial, ekonomi dan politik. Beberapa kajian tentang impak pelancongan terhadap kualiti hidup penduduk telah dilakukan bagi mengenal pasti penerimaan penduduk terhadap pembangunan pelancongan di sesebuah destinasi. Ini bagi memastikan industri dan aktiviti pelancongan dapat terus berkembang ataupun sebaliknya. Mohd Salleh et al. (2014) telah membuat kajian mengenai "Sustainable Livelihood and Community Perception of Tourism Development: A Case Study of Langkawi Island, Malaysia" yang menilai tahap kehidupan kelestarian masyarakat dan persepsi mereka mengenai kesan pembangunan pelancongan di Pulau Langkawi. Kajian ini menjelaskan pembangunan pelancongan di Pulau Langkawi memberi manfaat kepada komuniti dari segi kesejahteraan manusia, kewangan, fizikal dan sosial. Persepsi komuniti juga menyatakan bahawa pembangunan pelancongan dapat meningkatkan aspek ekonomi, sosial dan alam sekitar Pulau Langkawi. Seterusnya, Fandi (2014) yang mengkaji tentang "Analysis of Sustainable Tourism Livelihoods in Batu (East Java, Indonesia)". Kajian ini mendapati bahawa pelancongan dapat mewujudkan peluang pekerjaan baru, meningkatkan kualiti infrastruktur (jalan raya, air, elektrik dan pengangkutan awam), meningkatkan fenomena sosial dalam kalangan penduduk tempatan dan pembangunan pelancongan telah membuat masyarakat sedar bahawa mereka harus terlibat dan mengambil bahagian dalam pengurusan pelancongan untuk menjana pendapatan. Daripada kajian lepas jelas dapat dilihat bahawa pembangunan pelancongan di suatu tempat dapat memberi impak kepada komuniti setempat. Kesan-kesan ini dapat mempengaruhi ekonomi, alam sekitar, sosial dan budaya masyarakat tempatan. Hal ini sekali gus mempengaruhi kualiti hidup sesebuah komuniti.

\section{Objektif Kajian}

Kajian ini didokong dengan tiga objektif kajian, iaitu:

i. Mengenal pasti persepsi impak industri pelancongan (aspek ekonomi, sosial, budaya dan alam sekitar) dan kualiti hidup komuniti setempat di Batu Ferringhi.

ii. Menentukan hubungan antara persepsi impak industri pelancongan (aspek ekonomi, sosial, budaya dan alam sekitar) dan kualiti hidup komuniti setempat.

iii. Menentukan faktor-faktor peramal kualiti hidup komuniti setempat di Batu Ferringhi.

\section{Kajian Literatur}

\section{Industri Pelancongan di Pulau Pinang}

Pulau Pinang pada awalnya dikenali sebagai Pulau Ka Satu. Seorang pelayar yang bernama Ragam menemui Pulau Pinang sewaktu berulang-alik berdagang dari Lingga ke Kedah dan menamakan sedemikian kerana Pulau Pinang merupakan salah satu pulau besar yang terasing. Nama Pulau Ka Satu digunakan sehingga kedatangan British 1786. Apabila pokok pinang mula ditanam, nama pulau ini ditukar kepada Pulau Pinang. Manakala di Seberang Perai, penduduk lebih mengenali Pulau Pinang dengan nama Tanjong Penaga sempena nama pokok penaga yang tumbuh di sekitar Fort Cornwallis. Dipercayai nama ini atau singkatannya Tanjong masih digunakan dalam geran-geran tanah yang dikeluarkan oleh kerajaan sehingga tahun 1800. Malah, sehingga kini nama Tanjong begitu serasi dengan penduduk Pulau Pinang dan Seberang Perai apabila merujuk kepada Bandar Georgetown.

Kewujudan tinggalan warisan yang mempunyai nilai estetika, sejarah, saintifik dan sosial membolehkan Bandaraya Georgetown disenaraikan sebagai Tapak Warisan Dunia oleh UNESCO 
pada tahun 2008. Kepelbagaian budaya masyarakat di bandar ini juga telah menjadi salah satu produk tarikan pelancong. Pelbagai inisiatif telah dilakukan bagi memperluaskan usaha membaik pulih kawasan perniagaan tradisional seperti restoran, rumah kedai, bangunan komersial dan bangunan warung kopitiam yang telah beroperasi sejak 100 tahun yang dahulu. Signifikan warisan dan kebudayaan pelancongan terhadap peranan bandar ditonjolkan melalui penjenamaan sejarah perancangan bandar, susun atur zon kawasan guna tanah, seni bina bangunan dan fungsi reka bentuk pembandarannya yang unik. Hal ini merujuk kepada penyesuaian semula penggunaan bangunanbangunan bersejarah yang menghasilkan kesamaan fungsi dalam bentuk alam bina seperti kafe, kedaikedai cenderamata, kedai-kedai barangan, pusat perniagaan dan lain-lain aktiviti perdagangan yang beroperasi ketika ini. Hal ini tidak terkecuali melalui penonjolan konsep pelancongan pekan warisan etnik seperti "Little India" di Lebuh Chulia dan "Chinatown" di Lebuh Campbell.

\section{Implikasi Industri Pelancongan}

Impak merupakan tanda yang ditinggalkan oleh sesuatu yang melibatkan kebaikan dan keburukan. Menurut Brunner (2005), impak didefinisikan sebagai pengaruh pada pemikiran, sikap, watak dan sebagainya yang timbul akibat daripada mendengar atau membaca sesuatu sehingga mampu membawa kesan yang ketara. Bryman (2001) menyatakan bahawa impak berfungsi sebagai perbandingan antara hasil penelitian yang lepas dengan hasil penelitian yang baru atau yang telah dilakukan. Perkembangan industri pelancongan di sebuah kawasan atau destinasi yang berpotensi untuk dimajukan adalah amat digalakkan kerana industri pelancongan telah terbukti boleh menyumbangkan pelbagai impak yang positif terutama kepada golongan atau penduduk tempatan di kawasan tersebut. Impak positif yang dimaksudkan bukan sahaja melibatkan aspek sosioekonomi semata - mata bahkan turut melibatkan aspek sosial, budaya dan alam sekitar masyarakat tempatan.

Kajian Nordin \& Ahmad (2020) turut menyatakan penglibatan komuniti dalam aktiviti pelancongan dapat memberikan pelbagai impak positif kepada mereka. Antaranya adalah seperti dapat membantu mereka meningkatkan taraf ekonomi, sosial dan budaya (Salleh et al., 2012; Rosazman \& Velan, 2014). Hal ini kerana penduduk setempat mendapat peluang pekerjaan, menjual hasil produk tempatan dan mengusahakan perusahaan lain yang berkaitan dengan aktiviti pelancongan seperti menjadi pengusaha penginapan dan pengangkutan. Malahan, penglibatan komuniti dalam pembangunan produk pelancongan juga dapat membantu membangunkan keyakinan diri ahli-ahli komuniti melalui pengiktirafan yang diberikan oleh orang luar tentang keunikan nilai budaya mereka, sumber alam sekitar dan pengetahuan tradisi. Ini menyebabkan mereka mencari jalan untuk memajukan diri melalui pelbagai cara seperti mengikuti kursus bahasa asing dan latihan keusahawanan. Ini menunjukkan bahawa penglibatan komuniti dalam pembangunan pelancongan memberikan impak yang positif.

Pembangunan pelancongan sememangnya memberikan kesan kepada alam sekitar mahupun komuniti setempat sama ada secara langsung atau tidak langsung. Pembangunan yang dijalankan memberi impak yang besar kepada penduduk tempatan dalam pelbagai aspek positif walaupun terdapat juga impak negatif. Antaranya adalah perubahan taraf sosioekonomi kerana setelah pelaksanaan pembangunan pelancongan, ramai isi rumah yang menukar pekerjaan dengan menceburi sektor ekonomi yang lebih baik khususnya pelancongan iaitu sebagai pekerja di resort, pemandu pelancong, pemandu bot dan dive master.

Selain itu, Shudie dan Ghani (2020) juga telah menjalankan kajian mengenai impak pelancongan terhadap penduduk kampung di Mukah, Sarawak. Hasil kajian mendapati impak ekonomi utama yang diperoleh impak daripada industri pelancongan ialah banyak peluang pekerjaan diberikan kepada penduduk setempat. Antara peluang pekerjaan yang wujud adalah sebagai penari tradisional kaum Melanau, sebagai ahli pengurusan majlis, pemandu bot bagi membawa pelancong yang ingin melihat suasana kampung, pembuat kuih tradisional, kraf tangan dan pembuat Batik Linut. Kebanyakan golongan suri rumah yang terlibat dengan pembuatan kuih tradisional dan kraf tangan. Oleh itu, golongan suri rumah tidak terkecuali mendapat impak positif dari industri pelancongan. Budaya masyarakat setempat juga iaitu budaya kaum Melanau dapat diketengahkan di dalam industri pelancongan sehingga ke peringkat antarabangsa. Hal ini dapat dibuktikan dengan kedatangan pelancong-pelancong dari serata dunia seperti Jerman, Belanda, Itali, China dan Singapura. Selain itu, aktiviti pelancongan juga dilihat dapat menggalakkan pengekalan warisan budaya masyarakat 
setempat. Perkara ini telah mendorong penduduk setempat untuk mengamalkan dan mengekalkan amalan budaya nenek moyang mereka. Dari sudut infrastruktur dan persekitaran, impak pelancongan dilihat banyak penambahbaikan dilakukan untuk kemudahan pelancong seperti kemudahan jalan raya. Penduduk setempat yang tinggal berdekatan dengan kawasan pelancongan tersebut juga mendapat kebaikan daripada penambahbaikan infrastruktur yang dilakukan.

Berdasarkan hasil kajian Samad et al. (2013) pula mengenai impak pembangunan industri pelancongan kepada komuniti setempat, masyarakat tempatan meletakkan impak perkembangan pembangunan industri pelancongan dari aspek ekonomi menunjukkan persepsi yang positif dimana perkembangan industri pelancongan telah menyediakan peluang pekerjaan yang sesuai kepada masyarakat tempatan dan menggalakkan orang luar datang berbelanja. Ini memberi kesan kepada peningkatan pendapatan penduduk tempatan kerana peluang pekerjaan yang disediakan semakin meningkat terutamanya dari sektor perniagaan dan pelancongan. Namun begitu, perkembangan ini juga dikatakan memberi impak negatif kepada beberapa aspek seperti berlaku peningkatan sewaan rumah dan harga tanah di kawasan Pulau Langkawi. Manakala, dari aspek sosial daripada kajian ini menunjukkan perkembangan industri pelancongan telah mengubah cara hidup masyarakat dari segi hubungan kemasyarakatan dan tahap kepercayaan dalam kalangan masyarakat sekeliling. Perubahan yang berlaku ini dianggap negatif. Namun begitu, dari aspek budaya menunjukkan nilai kebudayaan dalam masyarakat tempatan semakin meningkat. Hal ini kerana disebabkan penggalakan aktiviti yang berbentuk kebudayaan dan kesenian. Aspek alam sekitar pula, secara keseluruhan perkembangan industri pelancongan di Pulau Langkawi telah membantu dalam menjaga alam semula jadi seperti hutan dan haiwan yang dilindungi semakin pupus. Namun hasil pembangunan di Pulau Langkawi telah menyebabkan berlakunya kesesakan lalu lintas.

Secara holistiknya, pembangunan merupakan satu proses yang mana membolehkan manusia menikmati manfaat daripadanya. Pembangunan bukan sahaja mengambil kira aspek fizikal iaitu infrastruktur, malah turut melibatkan proses menyusun dan menyelaras sistem ekonomi serta mengambil kira perubahan institusi sosial, adat resam dan kepercayaan komuniti setempat. Dalam konteks pelancongan, pembangunan mengambil kira sumbangannya terhadap komuniti tempatan yang meliputi pelbagai faktor seperti ekonomi, sosial dan budaya. Selain itu, pembangunan pelancongan juga melibatkan proses membangun, menyusun dan menaik taraf infrastruktur sesebuah kawasan pelancongan dengan mengambil kira faktor alam sekitar. Berdasarkan teori pembangunan kelestarian (Emas, 2015), pembangunan merangkumi tiga (3) faktor utama iaitu pembangunan ekonomi, pembangunan sosial budaya, pembangunan alam sekitar. Pembangunan ekonomi bermaksud pembangunan yang dapat mencipta peluang pekerjaan kepada komuniti tempatan atau komuniti tempatan mencipta perniagaan berasaskan pelancongan. Pembangunan sosial budaya pula ialah pembangunan yang membawa kepada kesejahteraan dan kualiti kehidupan yang lebih baik kepada komuniti tempatan. Manakala, pembangunan alam sekitar bermaksud pembangunan yang dapat mengekalkan sumber sedia atau memperbaharui sumber untuk faedah bersama untuk generasi masa kini dan generasi masa depan seperti mengelakkan daripada berlaku pencemaran alam sekitar.

\section{Kualiti Hidup}

Pelancongan merupakan sebuah industri yang kompleks sifatnya, dan merupakan satu sumber penjanaan pendapatan negara yang utama. Sektor ini juga dikatakan menjadi agen perubahan sosioekonomi penduduk bagi negara-negara sedang membangun. Peranan dan impak sektor pelancongan terhadap kesejahteraan dan kualiti hidup penduduk telah banyak dibincangkan oleh pengkaji sama ada di negara maju, negara sedang membangun ataupun di sesebuah destinasi terkemuka (Andereck et al., 2007; Yu et al., 2011). Hubungan antara sektor pelancongan dan kualiti hidup terserlah dalam konstruk seseorang individu dan komuniti bukan sahaja dalam aspek ekonomi, sosial dan persekitaran, malah ia menjangkau kepada peranan penduduk sebagai pengguna, penggiat, perancang pembangunan dan pengusaha pelancongan (Moscardo, 2009). Pelancongan, tidak kira apa pun produk, aktiviti dan pengalaman yang dianjurkan oleh sesebuah destinasi, secara idealnya berkait rapat dan saling mempengaruhi kesejahteraan hidup atau kualiti hidup penduduk (Aref, 2011). 
Kualiti hidup adalah istilah yang menyeluruh untuk kualiti pelbagai domain dalam kehidupan (Gregory, Johnston, Pratt, Watts, \& Whatmore, 2011). Ia adalah tahap standard yang terdiri daripada harapan individu atau masyarakat untuk kehidupan yang baik. Harapan ini dipandu oleh nilai-nilai, matlamat, serta konteks sosiobudaya di mana seseorang individu itu tinggal. Kualiti hidup berfungsi sebagai rujukan di mana individu mahupun kelompok masyarakat dapat mengukur indikator yang berbeza dalam kehidupan mereka. Ini menunjukkan seseorang individu itu mencapai tahap piawai kehidupan yang diingini adalah berbeza, di mana indikator ini memberikan kepuasan dan menyumbang kepada kesejahteraan seseorang, dan ia disebut sebagai kepuasan hidup. Walaupun pelbagai definisi dan indikator digunakan bagi menentukan kualiti hidup sosial, namun ia menjadi lambang kepada kemajuan negara (Peterson \& Malhotra, 2000). Ini bermaksud setiap penduduk mempunyai hak bagi mendapatkan serta menikmati kualiti hidup yang baik dan diperlukan.

Jabatan Perangkaan Malaysia menggunakan beberapa petunjuk asas untuk mengukur kualiti hidup dan kesejahteraan penduduk di peringkat kebangsaan dan negeri. Petunjuk utama yang diguna bagi melihat kualiti hidup meliputi penduduk, perumahan, kesihatan, pendidikan, pekerjaan, perkhidmatan kebajikan, keselamatan awam, serta komunikasi dan rekreasi (Jabatan Perangkaan Malaysia, 2019). Beberapa agensi kerajaan telah menjalankan kajian bagi mengukur kualiti hidup sosial dan kesejahteraan penduduk seperti Unit Perancang Ekonomi (EPU), Jabatan Perancangan Bandar dan Desa Semenanjung Malaysia (JPBD), dan Lembaga Penduduk dan Pembangunan Keluarga Negara (LPPKN). Indeks kualiti hidup dan kesejahteraan penduduk oleh EPU boleh dilihat melalui Laporan Kualiti Hidup Malaysia 1999-2011 (IKHM) dan Laporan Kesejahteraan Rakyat Malaysia manakala JPBD pula mengukur Indeks Kebahagiaan Malaysia dan bandar mampan melalui MURNInet 2.0, dan LPPKN dengan Indeks Kesejahteraan Keluarga (IKK).

Indeks Kualiti Hidup Malaysia (1999) diukur dengan menggunakan tahap pendapatan dan faktor bukan kewangan seperti kesejahteraan fizikal, psikologi dan sosial, kesihatan, keselamatan, perumahan, pendidikan, alam sekitar, budaya dan rekreasi, serta pengangkutan dan komunikasi. Beberapa komponen digunakan oleh EPU bagi menetapkan indeks kesejahteraan hidup iaitu kesejahteraan ekonomi, pendapatan dan pengagihan, pengangkutan, pendidikan, komunikasi, persekitaran kerja, kesejahteraan sosial, perumahan, masa lapang, keselamatan awam, tadbir urus, budaya, kesihatan, penglibatan sosial, alam sekitar, dan keluarga. IKHM merupakan ukuran komposit berdasarkan sepuluh komponen yang dipilih, iaitu, pendapatan dan pengagihan, persekitaran kerja, pengangkutan dan komunikasi, kesihatan, pendidikan, perumahan, alam sekitar, kehidupan keluarga, penyertaan sosial, dan keselamatan awam. Komponen ini dianggap sama penting bagi kesejahteraan dan kualiti hidup penduduk dan diberikan pemberat yang sama.

Secara keseluruhannya, peningkatan kualiti hidup masyarakat merupakan asas kepada penentuan tahap kemajuan dan kelestarian terhadap penghuninya. Melalui lima teras utama yang terkandung dalam Rancangan Malaysia ke-9 menekankan usaha meningkatkan tahap dan kemapanan kualiti hidup rakyat dengan menekankan kepada penyediaan keperluan asas dan penekanan kepada usaha-usaha menangani isu berhubung dengan penyelenggaraan, menaiktarafkan dan keberkesanan penggunaan sumber (Unit Perancang Ekonomi, Jabatan Perdana Menteri, 2015). Oleh itu, aspek kualiti hidup perlu dititikberatkan dalam setiap pembangunan yang dijalankan.

\section{Pembangunan Komuniti}

Komuniti dapat takrifkan sebagai kumpulan individu yang mendiami satu kawasan geografi, berinteraksi sesama mereka dalam satu jangka masa yang lama sehingga membentuk satu ikatan atau perhubungan bersama (Asnarulkahdi, 2003). Menurut sarjana lain, Ibrahim (2007) mentakrifkan komuniti sebagai sekumpulan kecil manusia yang tinggal di suatu per tempatan, mengamalkan suatu tahap autonomi dan cara hidup tersendiri, berkongsi aspirasi dan kehendak, berpartisipasi dalam aktiviti harian, bersatu padu dengan semangat kekitaan serta mempunyai kaitan yang rapat dalam semua aspek kehidupan. Berdasarkan definisi yang dikemukakan oleh kedua sarjana di atas, dapat dirumuskan bahawa sebuah komuniti mengandungi unsur-unsur yang sama iaitu manusia sama ada individu mahupun kumpulan, lokasi di mana mereka tinggal, interaksi di antara sesama mereka dalam 
jangka masa tertentu sehingga melahirkan amalan dan cara hidup dalam pelbagai aspek kehidupan seperti sosio ekonomi, budaya atau tradisi serta bahasa yang terhasil daripada interaksi tersebut.

Kejayaan perancangan pelancongan menghendaki penyertaan ataupun penglibatan penduduk tempatan (Hall, 2000). Oleh kerana itu, program-program pembangunan yang tidak melibatkan penduduk tempatan sentiasa mengalami kegagalan. Penglibatan penduduk harus dilaksanakan secara holistik mulai dari tahap perancangan, pelaksanaan hingga kepada pengawalan (Badaruddin, 2008). Beliau mengutarakan bahawa penyertaan atau penglibatan penduduk tempatan dalam program pembangunan pelancongan merupakan satu antara prinsip pelancongan lestari. Penglibatan penduduk sebagai satu bentuk tindakan sukarela di mana individu mengambil peluang dan memikul tanggungjawab masyarakat. Dengan perkataan lain, penglibatan penduduk berkait rapat dengan kerjasama antara penduduk di peringkat akar umbi dengan penggerak program yang berpotensi untuk meningkatkan kualiti hidup masyarakat setempat (Kalsom \& Nor, 2005).

Penglibatan penduduk tempatan kesan daripada dimajukannya sektor pelancongan memberikan pelbagai manfaat kepada ahli komuniti antaranya iaitu mewujudkan peluang pekerjaan kepada penduduk tempatan, penggunaan tenaga kerja dan sumber tempatan dalam pembinaan dan operasi penginapan, mewujudkan rasa bangga di kalangan penduduk dengan kehadiran pelancong serta peluang untuk pembangunan fizikal dengan penambahbaikan prasarana untuk kegunaan penduduk dan pelancong di kawasan itu (Ibrahim, 2008). Sementara itu, Murphy (1985) menyebutkan bahawa penglibatan penduduk tempatan juga dapat dijadikan sebagai alat untuk memelihara keunikan yang ada dalam suatu masyarakat. Setiap masyarakat berpegang pada adat yang diwarisi secara turun temurun dari dahulu melalui proses sosialisasi. Hampir semua golongan masyarakat kaya dengan pelbagai adat yang telah diatur oleh nenek moyang mereka sejak dari hari pertama kelahiran hinggalah saat kematian.

Hal ini seiring dengan konsep pembangunan lestari yang ditakrifkan oleh World Commission on Environment (WCED) sebagai satu pembangunan yang memenuhi kehendak semasa tanpa menjejaskan keupayaan generasi akan datang untuk memenuhi kehendak mereka sendiri (Hall, 2000). Justeru itu, pembangunan pelancongan yang lestari haruslah berupaya untuk sentiasa menghasilkan faedah ekonomi, sosial dan budaya yang kekal dan boleh diperbaharui kepada komuniti dana lam sekitar. Seandainya impak negatif daripada pelancongan dapat diminimumkan, ramai yang berpendapat bahawa pelancongan dapat menghasilkan pembangunan yang lestari. Sekiranya komuniti itu sendiri berupaya untuk menentukan dan mengawal pembangunan pelancongan dalam komuniti mereka, faedah pembangunan itu akan menjadi lebih baik dan sekali gus dapat meningkatkan kualiti hidup komuniti.

\section{Metod Kajian}

\section{Reka Bentuk Kajian}

Kajian ini adalah suatu kajian deskriptif dan korelasi yang menggunakan pendekatan kuantitatif dan reka bentuk tinjauan. Menurut Konting (2005), kajian deskriptif adalah kajian yang bermatlamat untuk menerangkan sesuatu fenomena yang sedang berlaku. Kajian korelasi mengkaji perkaitan antara pemboleh ubah-pemboleh ubah yang wujud dalam sesuatu masalah. Dalam kajian ini, pemboleh ubahpemboleh ubah yang dikaji ialah persepsi impak industri pelancongan dan kualiti hidup komuniti setempat. Jika wujud korelasi yang signifikan, maka terdapat hubungan antara kedua-dua pemboleh ubah tersebut. Arah hubungan antara kedua-dua pemboleh ubah tersebut juga dapat ditentukan sama ada berbentuk positif ataupun negatif.

\section{Populasi, Sampel dan Lokasi Kajian}

Populasi sasaran merujuk kepada jumlah kumpulan orang, peristiwa atau perkara yang ingin diselidiki oleh penyelidik. Individu dalam populasi berkongsi ciri yang sama.Beberapa langkah dalam pemilihan sampel kajian akan dilakukan untuk menentukan populasi dan saiz sampel dan seterusnya memilih 
DOI: https://doi.org/10.47405/mjssh.v6i8.978

sampel yang diperlukan. Populasi kajian ini adalah merujuk kepada bilangan komuniti setempat di kawasan Batu Ferringhi. Populasi komuniti di Batu Feringghi adalah seramai 13,728 orang warganegara Malaysia (Taburan Penduduk Mengikut Kawasan Pihak Berkuasa Tempatan dan Mukim, Pulau Pinang 2010). Kajian ini menggunakan formula pengiraan oleh Krejcie dan Morgan (1970) bagi mendapatkan bilangan saiz sampel. Berdasarkan jadual Krejcie dan Morgan (1970), bilangan yang saiz sampel terhampir adalah seramai 375 orang.

Pulau Pinang merupakan antara 10 negeri yang paling dilawati di Malaysia. Pada tahun 2019, Pulau Pinang berada kedudukan yang ke-8 dalam senarai negeri paling dilawati (Malaysia Tourism Statistics, 2019). Pulau Pinang menjadi destinasi pelancong tempatan dan juga antarabangsa. Adanya Lapangan Terbang Antarabangsa Pulau Pinang telah memudahkan pelancong dari luar negara untuk bercuti di negeri ini. Sejarah, kesenian dan kebudayaan serta kepelbagaian jenis makanan merupakan antara tarikan utama pelancong datang melancong ke Pulau Pinang. Pelancongan pantai juga merupakan tarikan pelancongan. Batu Ferrighi merupakan pantai yang paling terkenal di Pulau Pinang. Keindahan pantai dan aktiviti rekreasi air yang pelbagai menjadikan Batu Ferringhi tempat yang harus dilawati

\section{Proses Pensampelan}

Sampel adalah sebahagian individu daripada populasi yang sama yang terlibat dan terpilih dalam kajian. Jika sampel yang diambil dapat mewakili ciri populasi, maka data yang diperoleh daripada sampel membolehkan inferens atau kesimpulan tentang populasi dibuat tanpa perlu melakukan kajian terhadap keseluruhan individu dalam populasi tersebut (Othman, 2013). Dalam kajian ini, prosedur pemilihan sampel adalah secara teknik pensampelan rawak mudah berlapis. Satu set soal selidik diedarkan kepada komuniti setempat di sekitar Batu Ferringhi.

Tinjauan telah dilakukan dalam tempoh tertentu bagi mengumpul data berkenaan persepsi impak pembangunan pelancongan terhadap kualiti hidup komuniti setempat. Borang soal selidik diedarkan kepada responden melalui kaedah temu bual secara bersemuka. Pengkaji menjadi pemudah cara kepada responden bagi menjawab borang soal selidik. Hal ini dapat membantu responden sekiranya terdapat soalan yang tidak difahami dan dapat memastikan responden menjawab borang selidik dengan tepat tanpa bias. Di samping itu, temu bual bersemuka dapat memastikan borang selidik yang telah diedarkan kepada responden dikembalikan semula. Menerusi pensampelan rawak mudah berlapis, penyelidik telah melalui dua lapisan pemilihan sampel iaitu:

i. $\quad$ Sampel dibahagikan mengikut jalan yang dipilih.

ii. Sampel dipilih secara rawak dan setiap gandaan satu.

Berdasarkan Krejcie Morgan bilangan sampel adalah seramai 375 responden. Oleh itu sampel tersebut dibahagikan kepada 7 jalan utama yang dipilih.

$$
\begin{array}{ll}
\text { Saiz sampel } & =375 \\
\text { Jumlah jalan yang terlibat } & =7 \\
\text { Bilangan sampel bagi setiap jalan } & =375 / 7 \\
& =53.5 \text { (55 orang setiap jalan) }
\end{array}
$$

Sebagai langkah berjaga-jaga, penyelidik mengambil bilangan sampel lebih daripada bilangan sepatutnya berdasarkan jadual Krejcie dan Morgan 1970. Oleh itu, bilangan sampel setiap jalan adalah seramai 55 orang. Ini menjadikan jumlah sampel adalah seramai 385 orang. Namun begitu, analisis data menunjukkan hanya 383 orang sampel sahaja yang boleh digunakan.

\section{Dapatan Kajian}

Analisis Latar Belakang Responden 
DOI: https://doi.org/10.47405/mjssh.v6i8.978

Jadual 1 menunjukkan taburan latar belakang sosio-demografi responden dari segi jantina, bangsa, tahap pendidikan, umur, status pekerjaan, penglibatan pekerjaan dalam industri pelancongan serta kategori pendapatan bulanan. Daripada 383 responden, seramai 175 orang (45.7\%) terdiri daripada responden lelaki manakala 208 orang $(54.3 \%)$ adalah responden perempuan. Selain itu, majoriti responden adalah berbangsa Melayu iaitu seramai 178 orang (46.5\%) diikuti dengan bangsa Cina seramai 116 orang (30.3\%), India seramai 74 orang (19.3\%) dan lain-lain seramai 15 orang (3.9\%). Berdasarkan Jadual 1 juga menunjukkan seramai 217 orang $(56.7 \%)$ yang mempunyai tahap pendidikan SPM, manakala 112 orang $(29.2 \%)$ dan 26 orang $(6.8 \%)$ mempunyai pendidikan di tahap STPM/Diploma/Sijil dan Ijazah. Di samping itu, seramai 11 orang (2.9\%) mempunyai pendidikan di tahap PMR/PT3 dan seramai 7 orang $(1.8 \%)$ yang mempunyai pendidikan di tahap UPSR. Terdapat juga responden yang tidak bersekolah iaitu seramai 10 orang $(2.6 \%)$.

Jadual 1: Taburan latar belakang demografi responden $(\mathrm{N}=383)$

\begin{tabular}{|c|c|c|}
\hline Item & Kekerapan & Peratusan (\%) \\
\hline \multicolumn{3}{|l|}{ Jantina } \\
\hline Lelaki & 175 & 45.7 \\
\hline Perempuan & 208 & 54.3 \\
\hline \multicolumn{3}{|l|}{ Bangsa } \\
\hline Melayu & 178 & 46.5 \\
\hline Cina & 116 & 30.3 \\
\hline India & 74 & 19.3 \\
\hline Lain-lain & 15 & 3.9 \\
\hline \multicolumn{3}{|l|}{ Tahap Pendidikan } \\
\hline Tidak Bersekolah & 10 & 2.6 \\
\hline UPSR & 7 & 1.8 \\
\hline PMR/PT3 & 11 & 2.9 \\
\hline SPM & 217 & 56.7 \\
\hline STPM/Diploma/Sijil & 112 & 29.2 \\
\hline Ijazah & 26 & 6.8 \\
\hline \multicolumn{3}{|l|}{ Umur } \\
\hline$\leq 20$ & 79 & 20.7 \\
\hline $21-30$ & 188 & 49.0 \\
\hline $31-40$ & 42 & 11.0 \\
\hline $41-50$ & 63 & 16.3 \\
\hline$\geq 51$ & 11 & 3.0 \\
\hline \multicolumn{3}{|l|}{ Status Pekerjaan } \\
\hline Sektor Awam & 55 & 14.4 \\
\hline Sektor Swasta & 132 & 34.5 \\
\hline Bekerja Sendiri & 115 & 30.0 \\
\hline Tidak Bekerja & 81 & 21.1 \\
\hline \multicolumn{3}{|c|}{ Pekerjaan Terlibat dengan Industri Pelancongan } \\
\hline Terlibat & 245 & 64.0 \\
\hline Tidak Terlibat & 57 & 14.9 \\
\hline Tidak Berkenaan & 81 & 21.1 \\
\hline \multicolumn{3}{|l|}{ Kategori Pendapatan Bulanan } \\
\hline B40 $(<$ RM 3,860) & 278 & 72.6 \\
\hline M40 (RM 3,860 - RM 8,319) & 102 & 26.6 \\
\hline T20 (>RM 8,319) & 3 & 0.8 \\
\hline
\end{tabular}

Taburan latar belakang responden menunjukkan majoriti responden berumur 21-30 tahun iaitu seramai 188 orang $(49.0 \%)$ dan responden yang berumur bawah dari 20 tahun adalah kedua teramai iaitu 79 orang (20.7\%). Bagi responden golongan umur 31-40 tahun dan 41-50 tahun masing-masing adalah seramai 42 orang $(11.0 \%)$ dan 63 orang $(16.3 \%)$. Terdapat juga responden yang berumur lebih daripada 50 tahun iaitu seramai 11 orang $(3.0 \%)$. 
DOI: https://doi.org/10.47405/mjssh.v6i8.978

Seterusnya, kebanyakan responden terdiri daripada pekerja dari sektor swasta iaitu seramai 132 orang (34.5\%) dan diikuti dengan bekerja sendiri iaitu seramai 115 orang (30.0\%). Hanya 55 orang (14.4\%) yang bekerja di sektor awam dan seramai 82 orang (21.2\%) tidak bekerja. Taburan latar belakang responden juga menunjukkan seramai 245 orang $(64.0 \%)$ yang bekerja dan terlibat dengan industri pelancongan. Hal ini kerana kawasan kajian merupakan kawasan tarikan pelancongan di Pulau Pinang dan banyak aktiviti ekonomi berdasarkan industri pelancongan dijalankan. Di samping itu, seramai 57 orang (14.9\%) bekerja dan tidak terlibat dengan industri pelancongan. Manakala selebihnya tidak berkenaan dengan industri pelancongan, 81 orang $(21.1 \%)$.

Bagi taburan kategori pendapatan bulanan pula, seramai 278 orang $(72.6 \%)$ terdiri daripada golongan B40 (< RM 3,860). Seterusnya, bagi M40 (RM 3,860 - RM 8,319) pula adalah seramai 120 orang (31.3\%) dan golongan T20 (>RM 8,319) adalah seramai 3 orang $(0.8 \%)$

\section{Persepsi Impak Industri Pelancongan dan Kualiti Hidup}

Berdasarkan Jadual 3, hasil kajian dan analisis mendapati majoriti responden memberikan persepsi positif terhadap keempat-empat aspek impak industri pelancongan iaitu pada sangat tinggi bagi aspek ekonomi $(49.5 \%, \min =4.17)$ dan budaya $(52.0 \%$, $\min =4.27)$. Manakala bagi aspek sosial pula adalah $(73.0 \%, \min =3.38)$ dan alam sekitar $(55.5 \%$, min=3.70) iaitu pada tahap tinggi.

Jadual 2: Interpretasi Nilai Min

\begin{tabular}{|c|c|c|c|c|c|}
\hline Skala Likert & 1 & 2 & 3 & 4 & 5 \\
\hline $\begin{array}{l}\text { Interpretasi Skala } \\
\text { Likert }\end{array}$ & $\begin{array}{l}\text { Sangat } \\
\text { Tidak Setuju }\end{array}$ & Tidak Setuju & Neutral & Setuju & $\begin{array}{l}\text { Sangat } \\
\text { Setuju }\end{array}$ \\
\hline Nilai Nilai Min & $1.00-1.99$ & $2.00-2.99$ & 3.00 & $3.01-4.00$ & $4.01-5.00$ \\
\hline Interpretasi Nilai Min & $\begin{array}{l}\text { Sangat } \\
\text { Rendah }\end{array}$ & Rendah & Sederhana & Tinggi & $\begin{array}{l}\text { Sangat } \\
\text { Tinggi }\end{array}$ \\
\hline
\end{tabular}

Jadual 3: Persepsi Impak Industri Pelancongan

\begin{tabular}{lllllll}
\hline Persepsi Impak Industri Pelancongan & n & \% & Purata & SP & Min & Mak \\
\hline Aspek Ekonomi & & & 4.17 & 0.58 & 2.60 & 5.00 \\
Rendah & 9 & 2.4 & & & & \\
Sederhana & 8 & 2.1 & & & & \\
Tinggi & 63 & 46.0 & & & & \\
Sangat Tinggi & 190 & 49.5 & & & & \\
Aspek Sosial & & & 3.38 & 0.48 & 2.20 & 4.60 \\
Rendah & 58 & 15.1 & & & & \\
Sederhana & 12 & 3.1 & & & & \\
Tinggi & 279 & 73.0 & & & & \\
Sangat Tinggi & 34 & 8.8 & & & & \\
& & & & & & \\
Aspek Budaya & & & 4.27 & 0.50 & 3.00 & 5.00 \\
Sederhana & 4 & 1.0 & & & & \\
Tinggi & 180 & 47.0 & & & & \\
Sangat Tinggi & 199 & 52.0 & & & & \\
Aspek Alam Sekitar & & & & & \\
Rendah & & & 3.70 & 0.64 & 2.30 & 5.00 \\
Sederhana & 50 & 12.9 & & & & \\
Tinggi & 4 & 1.0 & & & & \\
Sangat Tinggi & 213 & 55.5 & & & & \\
\end{tabular}


Berdasarkan hasil analisis kajian yang telah dijalankan, komuniti setempat memberi persepsi bahawa implikasi pelancongan dapat menggalakkan aktiviti ekonomi. Banyak peluang pekerjaan berkaitan pelancongan akan dan telah diwujudkan seperti pembukaan kedai runcit, kraf tangan dan cenderamata untuk para pelancong. Selain itu, perniagaan perkhidmatan yang berasaskan aktiviti air juga boleh diperkembangkan dan telah banyak dibuka seperti jetski, banana bot dan sebagainya. Perkara ini selari dengan kajian lepas di mana impak industri pelancongan telah menyediakan peluang pekerjaan yang sesuai kepada masyarakat tempatan dan menggalakkan orang luar datang berbelanja (Samad et al., 2013).

Seterusnya, bagi aspek sosial pula, hasil analisis kajian menunjukkan komuniti setempat memberi persepsi bahawa industri pelancongan mampu memberi impak kepada peningkatan kemahiran komunikasi dalam kalangan komuniti setempat. Komuniti setempat dikatakan sering berinteraksi dengan para pelancong dan secara tidak langsung mereka dapat mempelajari dan mengamalkan bahasa asing dalam kehidupan seharian mereka. Hal ini dapat dirujuk dari kajian lepas di mana Salleh et al. (2017) menyatakan bahawa pembangunan pelancongan dapat meningkatkan keupayaan komuniti berkomunikasi dalam bahasa asing terutamanya Bahasa Inggeris dengan pelancong luar.

Impak pelancongan dari aspek budaya dapat dilihat melalui wujudnya komuniti setempat yang cintakan budaya. Hasil analisis kajian menunjukkan komuniti setempat terlibat sama dalam pemuliharaan kawasan sejarah dan memelihara identiti budaya masyarakat di sana. Antara salah satu elemen budaya yang diketengahkan di kawasan tersebut adalah batik. Ini dapat dilihat dengan adanya kilang batik iaitu Craft Batik yang dijadikan sebagai salah satu tarikan pelancongan di kawasan tersebut. Selari dengan kajian lepas di mana Samad et al. (2013) menyatakan nilai kebudayaan dalam masyarakat tempatan semakin meningkat. Hal ini disebabkan penggalakan aktiviti yang berbentuk kebudayaan dan kesenian.

Seterusnya dari aspek alam sekitar, hasil analisis kajian menunjukkan komuniti setempat memberi persepsi bahawa industri pelancongan mampu untuk meningkatkan imej dan pemandangan kampung. Di samping itu, pelancongan telah mendorong pembangunan taman-taman riadah dan rekreasi kawasan setempat. Hal ini dapat dilihat di mana terdapat Taman Negara Pulau Pinang berdekatan dengan kawasan pelancongan Batu Ferringhi. Secara tidak langsung, ini menggalakkan pemuliharaan alam semula jadi dalam kalangan komuniti setempat. Oleh itu, kajian ini bersetuju dengan kajian lepas oleh Salleh et al. (2017) di mana pelancongan telah membawa peningkatan imej dan pemandangan kampung tradisional Melayu. Selain itu, industri pelancongan juga turut meningkatkan pemuliharaan alam sekitar di kawasan yang terlibat.

\section{Kualiti Hidup Komuniti Setempat}

Hasil kajian menunjukkan majoriti responden mempunyai persepsi positif yang sangat tinggi terhadap kualiti hidup dari elemen Kebudayaan dan Liburan $(54.7 \%$, min=4.32), Pengangkutan dan Komunikasi $(53.7 \%$, $\min =4.33)$ dan Persekitaran Kerja $(52.8 \%, \min =4.37)$. Manakala, elemen selebihnya berada pada tahap tinggi iaitu, Pendidikan $(51.4 \%, \min =4.30)$, Perumahan $(50.1 \%$, $\min =4.22)$, Pendapatan dan Pengagihan $(58.7 \%, \min =4.11)$, Keselamatan Awam $(42.5 \%, \min =3.54)$, Kesihatan $(56.4 \%, \min =3.79)$, Penyertaan Sosial $(57.2 \%, \min =4.27)$, Alam Sekitar $(36.5 \%, \min =3.42)$ dan Kehidupan Keluarga $(55.1 \%, \min =4.11)$.

Berdasarkan hasil analisis kajian, terdapat tiga elemen kualiti hidup yang paling terkesan dengan industri pelancongan iaitu elemen persekitaran kerja, pengangkutan dan komunikasi serta kebudayaan dan liburan. Dari elemen persekitaran kerja menunjukkan hasil pembangunan pelancongan telah dapat mewujudkan persekitaran yang lebih baik. Kewujudan pelbagai peluang pekerjaan seperti pengurus hotel, kakitangan di syarikat bas serta usahawan agensi pelancongan membolehkan komuniti setempat mendapat pendedahan untuk menceburi perniagaan baharu yang menguntungkan serta mampu berdikari. Peluang dan persekitaran pekerjaan yang baik mampu meningkatkan taraf sosioekonomi 
DOI: https://doi.org/10.47405/mjssh.v6i8.978

komuniti setempat serta mencapai hasrat kerajaan dalam mengurangkan kadar kemiskinan dan pengangguran.

Jadual 4: Elemen-elemen Kualiti Hidup

\begin{tabular}{|c|c|c|c|c|c|c|}
\hline Kualiti Hidup & $\mathbf{n}$ & $\%$ & Purata & SP & Min & Mak \\
\hline Pendidikan & & & 4.30 & 0.57 & 2.67 & 5.00 \\
\hline Rendah & 3 & 0.8 & & & & \\
\hline Sederhana & 1 & 0.3 & & & & \\
\hline Tinggi & 197 & 51.4 & & & & \\
\hline Sangat Tinggi & 182 & 47.5 & & & & \\
\hline Pengangkutan dan Komunikasi & & & 4.33 & 0.56 & 3.00 & 5.00 \\
\hline Sederhana & 5 & 1.3 & & & & \\
\hline Tinggi & 172 & 44.9 & & & & \\
\hline Sangat Tinggi & 206 & 53.7 & & & & \\
\hline Perumahan & & & 4.22 & 0.59 & 2.33 & 5.00 \\
\hline Rendah & 9 & 2.4 & & & & \\
\hline Sederhana & 6 & 1.6 & & & & \\
\hline Tinggi & 192 & 50.1 & & & & \\
\hline Sangat Tinggi & 176 & 45.9 & & & & \\
\hline Kebudayaan dan Liburan & & & 4.32 & 0.56 & 2.67 & 5.00 \\
\hline Rendah & 3 & 0.8 & & & & \\
\hline Sederhana & 5 & 1.3 & & & & \\
\hline Tinggi & 165 & 43.2 & & & & \\
\hline Sangat Tinggi & 210 & 54.7 & & & & \\
\hline Pendapatan dan Pengagihan & & & 4.11 & 0.60 & 2.33 & 5.00 \\
\hline Rendah & 9 & 2.3 & & & & \\
\hline Sederhana & 14 & 3.7 & & & & \\
\hline Tinggi & 225 & 58.7 & & & & \\
\hline Sangat Tinggi & 135 & 35.3 & & & & \\
\hline Keselamatan Awam & & & 3.54 & 0.79 & 2.00 & 5.00 \\
\hline Rendah & 70 & 18.3 & & & & \\
\hline Sederhana & 87 & 22.7 & & & & \\
\hline Tinggi & 163 & 42.5 & & & & \\
\hline Sangat Tinggi & 63 & 16.5 & & & & \\
\hline Kesihatan & & & 3.79 & 0.76 & 2.00 & 5.00 \\
\hline Rendah & 42 & 11.0 & & & & \\
\hline Sederhana & 27 & 7.0 & & & & \\
\hline Tinggi & 216 & 56.4 & & & & \\
\hline Sangat Tinggi & 98 & 25.5 & & & & \\
\hline Penyertaan Sosial & & & 4.27 & 0.58 & 2.00 & 5.00 \\
\hline Rendah & 4 & 1.0 & & & & \\
\hline Sederhana & 10 & 2.6 & & & & \\
\hline Tinggi & 219 & 57.2 & & & & \\
\hline Sangat Tinggi & 150 & 39.1 & & & & \\
\hline Alam Sekitar & & & 3.42 & 1.05 & 1.00 & 5.00 \\
\hline Sangat Rendah & 18 & 4.7 & & & & \\
\hline Rendah & 94 & 24.6 & & & & \\
\hline
\end{tabular}



DOI: https://doi.org/10.47405/mjssh.v6i8.978

$\begin{array}{lllllll}\text { Sederhana } & 46 & 12.0 & & & & \\ \text { Tinggi } & 140 & 36.5 & & & & \\ \text { Sangat Tinggi } & 85 & 22.2 & & & & \\ & & & & & & \\ \text { Kehidupan Keluarga } & & & 4.11 & 0.70 & 2.00 & 5.00 \\ \text { Rendah } & 9 & 2.4 & & & & \\ \text { Sederhana } & 26 & 6.8 & & & & \\ \text { Tinggi } & 211 & 55.1 & & & & \\ \text { Sangat Tinggi } & 137 & 35.7 & & & & \\ & & & & & & \\ \text { Persekitaran Kerja } & & & 4.37 & 0.53 & 2.67 & 5.00 \\ \text { Rendah } & 1 & 0.3 & & & & \\ \text { Sederhana } & 12 & 3.1 & & & & \\ \text { Tinggi } & 168 & 43.9 & & & & \\ \text { Sangat Tinggi } & 202 & 52.8 & & & & \\ & & & & & \end{array}$

Seterusnya, dari elemen pengangkutan dan komunikasi pula wujudnya kemudahan pengangkutan awam hasil daripada pembangunan pelancongan. Perkara ini dapat dilihat dengan adanya Rapid Penang sejak 2007 bagi memudahkan pelancong bergerak dari satu tempat ke tempat lain. Kemudahan pengangkutan ini juga telah memudahkan pelancong akses dari bandar ke batu Ferringhi untuk menikmati pelancongan pantai pula. Dengan adanya kemudahan ini, berlakunya peningkatan keluar masuk pelancong ke Batu Ferringhi dan ini sekali gus dapat membantu menjana pendapatan komuniti setempat.

Selain itu, bagi elemen kebudayaan dan liburan dan meningkatkan kualiti hidup dengan dapat mengekalkan gaya hidup komuniti setempat dan wujudnya aktiviti kebudayaan. Selari dengan Samad et. al (2013), aspek budaya menunjukkan nilai kebudayaan dalam masyarakat tempatan semakin meningkat. Hal ini kerana disebabkan penggalakan aktiviti yang berbentuk kebudayaan dan kesenian. Dengan adanya kilang batik yang berhampiran dengan Batu Ferringhi, komuniti setempat dapat memperkenalkan budaya setempat kepada pelancong luar. Dalam masa yang sama pelbagai aktiviti kebudayaan dan kesenian dijalankan bagi mendidik dan memelihara budaya dan seni dari turun temurun.

\section{Hubungan antara persepsi impak industri pelancongan (aspek ekonomi, sosial, budaya dan alam sekitar) dan kualiti hidup komuniti setempat di Batu Ferringhi}

Hubungan antara pemboleh ubah bersandar ialah kualiti hidup dan pemboleh ubah tidak bersandar ialah persepsi impak industri pelancongan dari aspek ekonomi, sosial, budaya dan alam sekitar. Penggunaan korelasi Pearson mengesahkan hubungan antara pemboleh ubah bersandar dan tidak bersandar bagi membuktikan hipotesis kajian. Kekuatan nilai korelasi Pearson kajian ini telah ditentukan menggunakan garis panduan yang disarankan oleh Cohen (1988) seperti dalam Jadual 5.

Jadual 5: Interpretasi Kekuatan Nilai Kolerasi

\begin{tabular}{ll}
\hline Nilai Kolerasi $(\mathbf{r})$ & Kekuatan Hubungan \\
\hline 0.10 hingga 0.29 & Lemah \\
0.30 hingga 0.49 & Sederhana \\
0.50 hingga 1.0 & Kuat \\
\hline
\end{tabular}

Objektif kedua kajian ini adalah untuk menentukan hubungan antara persepsi impak pembangunan pelancongan (aspek ekonomi, sosial, budaya dan alam sekitar) dan kualiti hidup komuniti setempat. Empat hipotesis kajian yang dibina adalah seperti di bawah:

Ho1a: Tidak terdapat hubungan antara persepsi impak industri pelancongan dari aspek ekonomi dengan kualiti hidup komuniti setempat di Batu Ferringhi. 
DOI: https://doi.org/10.47405/mjssh.v6i8.978

Ho1b: Tidak terdapat hubungan antara persepsi impak industri pelancongan dari aspek sosial dengan kualiti hidup komuniti setempat di Batu Ferringhi.

Ho1c: Tidak terdapat hubungan antara persepsi impak industri pelancongan dari aspek budaya dengan kualiti hidup komuniti setempat di Batu Ferringhi.

Ho1d: Tidak terdapat hubungan antara persepsi impak industri pelancongan dari aspek alam sekitar dengan kualiti hidup komuniti setempat di Batu Ferringhi.

Untuk menguji beberapa hubungan pemboleh ubah, ujian korelasi Pearson telah dilakukan ke atas semua pemboleh ubah yang terlibat. Jadual 6 menunjukkan hubungan antara pemboleh ubahpemboleh ubah yang dikaji.

Jadual 6: Analisis Kolerasi Pearson

\begin{tabular}{|c|c|c|c|c|c|}
\hline & Kualiti Hidup & Ekonomi & Sosial & Budaya & $\begin{array}{l}\text { Alam } \\
\text { Sekitar }\end{array}$ \\
\hline Kualiti Hidup & - & - & - & - & - \\
\hline Ekonomi & $\begin{array}{l}0.518 * * \\
(0.000)\end{array}$ & - & - & - & - \\
\hline Sosial & $\begin{array}{l}0.420 * * \\
(0.000)\end{array}$ & $\begin{array}{l}0.264 * * \\
(0.000)\end{array}$ & - & - & - \\
\hline Budaya & $\begin{array}{l}0.629 * * \\
(0.000)\end{array}$ & $\begin{array}{l}0.634 * * \\
(0.000)\end{array}$ & $\begin{array}{l}0.542^{* *} \\
(0.000)\end{array}$ & - & - \\
\hline Alam Sekitar & $\begin{array}{l}0.627 * * \\
(0.000)\end{array}$ & $\begin{array}{l}0.344 * * \\
(0.000)\end{array}$ & $\begin{array}{l}0.737 * * \\
(0.000)\end{array}$ & $\begin{array}{l}0.654 * * \\
(0.000)\end{array}$ & - \\
\hline
\end{tabular}

Nota: $* * \mathrm{p}<.01$

Keputusan dalam Jadual 6 menunjukkan terdapat hubungan antara keempat-empat aspek persepsi impak industri pelancongan dengan kualiti hidup. Kesemua aspek menunjukkan hubungan signifikan secara positif iaitu aspek ekonomi $\left(\mathrm{r}=0.518^{* *}, \mathrm{p}<0.01\right)$, aspek sosial $\left(\mathrm{r}=0.420^{* *}, \mathrm{p}<0.01\right)$, aspek budaya $\left(\mathrm{r}=0.629^{* *}, \mathrm{p}<0.01\right)$ dan alam sekitar $\left(\mathrm{r}=0.627^{* *}, \mathrm{p}<0.01\right)$. Oleh itu, hipotesis Ho1a, Ho1b, Ho1c dan Ho1d tidak diterima kerana terdapat hubungan yang signifikan antara keempat-empat aspek persepsi impak industri pelancongan dengan kualiti hidup.

Berdasarkan hasil analisis kajian, persepsi impak industri pelancongan dari aspek ekonomi, sosial, budaya dan alam sekitar boleh mempengaruhi kualiti hidup komuniti setempat. Hasil kajian ini selari dengan kajian lepas di mana kajian oleh Ridho et al. (2016) menyatakan terdapat perkaitan di antara keempat-empat aspek tersebut dengan kualiti hidup. Dari aspek ekonomi dapat dilihat mampu meningkatkan taraf hidup komuniti setempat di kawasan luar bandar dengan memberikan peluang pekerjaan. Bagi aspek sosial pula, persepsi industri pelancongan boleh meningkatkan keupayaan komuniti berkomunikasi dalam bahasa asing dengan para pelancong. Industri ini juga dapat meningkatkan cara hidup di mana komuniti setempat ini lebih terdedah dengan unsur kemajuan untuk mencapai kualiti hidup yang lebih baik. Seterusnya dari aspek budaya, industri pelancongan membawa kepada pengukuhan budaya masyarakat dan berpeluang mengekalkan identiti komuniti setempat. Akhir sekali, dari aspek alam sekitar pula telah mendorong komuniti setempat untuk menjaga imej kampung atau destinasi pelancongan. Oleh itu, lebih banyak galakan pemuliharaan alam sekitar dijalankan bagi menjaga kualiti alam sekitar. Secara holistiknya, impak positif yang diterima dari pembangunan pelancongan boleh meningkatkan kualiti hidup komuniti setempat.

\section{Analisis Faktor-Faktor Peramal Kualiti Hiduup Komuniti Setempat di Batu Ferringhi}

Bagi menguji pengaruh antara kualiti hidup dengan pemboleh ubah peramal iaitu persepsi impak industri pelancongan dari aspek ekonomi, sosial, budaya dan alam sekitar, hipotesis Ho12 telah dibina 
iaitu tidak terdapat pengaruh yang signifikan antara kualiti hidup dengan pemboleh ubah peramal iaitu persepsi impak industri pelancongan dari aspek ekonomi, sosial, budaya dan alam sekitar.

Ho2a: Tidak terdapat pengaruh yang signifikan antara kualiti hidup dengan pemboleh ubah peramal iaitu persepsi impak industri pelancongan dari aspek ekonomi,

Ho2b: Tidak terdapat pengaruh yang signifikan antara kualiti hidup dengan pemboleh ubah peramal iaitu persepsi impak industri pelancongan dari aspek sosial.

Ho2c: Tidak terdapat pengaruh yang signifikan antara kualiti hidup dengan pemboleh ubah peramal iaitu persepsi impak industri pelancongan dari aspek budaya.

Ho2d: Tidak terdapat pengaruh yang signifikan antara kualiti hidup dengan pemboleh ubah peramal iaitu persepsi impak industri pelancongan dari aspek alam sekitar.

Jadual 7: Regresi berganda antara persepsi implikasi industri pelancongan dengan kualiti hidup

\begin{tabular}{llllll}
\hline Item & $\boldsymbol{R}$ Square & $\boldsymbol{F}$ & Coefficients, $\boldsymbol{B}$ & $\boldsymbol{t}$ & Sig. \\
\hline & 0.520 & 102.292 & & & 0.000 \\
Constant & & & & 9.869 & 0.000 \\
Ekonomi & & & 0.241 & 5.187 & 0.000 \\
Sosial & & -0.127 & -2.386 & 0.018 \\
Budaya & & 0.222 & 3.823 & 0.000 \\
Alam Sekitar & & 0.492 & 8.319 & 0.000 \\
\hline
\end{tabular}

Berdasarkan Jadual 7 menunjukkan kualiti hidup sebagai ukuran pemboleh ubah bersandar dan empat pemboleh ubah iaitu aspek ekonomi, sosial, budaya dan alam sekitar sebagai faktor peramal. Keempatempat peramal menjelaskan sebahagian besar perbezaan, $\mathrm{R}^{2}=0.520, \mathrm{~F}(4,383)=102.292$, p $0.000<$ 0.05 . Oleh itu, keempat-empat aspek tersebut mempengaruhi kualiti hidup sebanyak $52 \%$ dan selebihnya adalah pengaruh lain-lain. Hubungan aspek ekonomi dengan kualiti hidup adalah $(\beta=$ $0.241, \mathrm{p}=0.000<0.05)$, aspek sosial $(\beta=-0.127, \mathrm{p}=0.018<0.05)$, aspek budaya $(\beta=3.823, \mathrm{p}=0.000$ $<0.05)$ dan aspek alam sekitar $(\beta=8.319, \mathrm{p}=0.000<0.05)$. Hasil kajian menunjukkan hipotesis Ho2a, Ho2b, Ho2c dan Ho2d tidak diterima kerana terdapat pengaruh signifikan antara persepsi impak industri pelancongan dalam mempengaruhi kualiti hidup komuniti setempat di Batu Ferringhi.

\section{Kesimpulan}

Secara holistiknya, industri pelancong boleh memberi implikasi positif dan negatif kepada perkembangan dan pembangunan komuniti setempat di sesebuah kawasan pelancongan. Komuniti setempat di Batu Ferringhi memberi anggapan persepsi impak industri pelancongan sebagai impak yang positif kepada aspek ekonomi, sosial, budaya serta alam sekitar terhadap kualiti hidup mereka. Impak industri pelancongan juga dikatakan saling mempengaruhi kualiti hidup komuniti setempat. Oleh itu, pembangunan industri pelancongan haruslah menitikberatkan aspek kehidupan komuniti setempat dalam memastikan setiap individu mendapat manfaat dari pembangunan yang dijalankan. Pembangunan yang dilakukan juga perlulah seimbang dari semua aspek bagi mencapai pembangunan komuniti dan pelancongan yang lestari dan berkualiti.

\section{Penghargaan}

Penghargaan kepada Komuniti Tempatan Batu Ferringghi, Pulau Pinang atas kesudian untuk bekerjasama dalam pengumpulan data bagi menjayakan kajian ini. 


\section{Rujukan}

Afandi, A., Ananda, C. F., Maskie, G., \& Khusaini, M. (2014). Analysis of sustainable tourism livelihoods in Batu (East Java, Indonesia): SLFT approach (Sustainable Livelihood Framework for Tourism). Journal of Economics and Sustainable Development, 5(10), 148-156.

Ahmad, J. A. I. M. Z., Ibrahim, J. A., \& Zakaria, N. (2011). Inap desa sebagai satu agen pembangunan sosioekonomi komuniti: Menelusuri perspektif pelajar-pelajar pengurusan pelancongan UUM. Prosiding Perkem VI, JILID, 2, 481-493.

Andereck, K. L., Valentine, K. M., Vogt, C. A. \& Knopf, R.C. (2007). A cross-cultural analysis of tourism and quality of life perceptions. Journal of Sustainable Tourism 15(5): 483-502.

Aref, F. 2011. The effects of tourism on quality of life: A Case Study of Shiraz, Iran. Life Science Journal 8(2): 26-30.

Asnarulkahdi Abusamah (2003). Pengenalan Pembangunan Komuniti. Selangor: Percetakan Selasih Sdn Bhd, 2003.

Azemi Che Hamid (2006). Persepsi Kualiti Hidup: Satu Tinjauan Ke Atas Penduduk Bandar Seri Kertih, Kemaman, Terengganu dalam Norhaslina Hassan 2006. Dinamika Masyarakat Bandar Malaysia: Ke Arah Kualiti Hidup Mapan. Kuala Lumpur. Penerbit Universiti Malaya.

Badaruddin Mohamed (2008). Pelancongan Lestari. Kuala Lumpur: Dewan Bahasa dan Pustaka.

Brunner, E. (2005). Culture on Tour: Ethnographies of Travel. Chicago: University of Chicago Press.

Bryman, A. (2001). Sosial Research Methods. Oxford: Oxford University Press.

Cohen, J. (1988). Statistical power analysis for the behavioral sciences (2nd ed.). New York: John Wiley.

Eshliki, S. A., \& Kaboudi, M. (2012). Community Perception of Tourism Impacts and Their Participation in Tourism Planning: A Case Study of Ramsar, Iran. Procedia-Social and Behavioral Sciences, 36, 333-341.

George, G., \& Mallery, P. (2003). SPSS for windows step by step: a simple guide and reference, 11.0 update. Boston, MA: Allyn \& Bacon

Gregory, D., Johnston, R., Pratt, G., Watts, M., \& Whatmore, S. (2011). The dictionary of human geography. Oxford: John Wiley \& Sons.

Hall, C.M., (2000). Tourism planning: Policies, processes and relationships (1st ed.). Essex: Pearson Education Limited, 2000.

Hua, A. K. (2017). Melaka sebagai pusat pelancongan dunia: Dapatkah dipertahankan? (Malacca as a world tourism centre: Is it sustainable?). Geografia-Malaysian Journal of Society and Space, 11(9).

Ibrahim, Y. (2006). Komuniti Melayu Pulau Tioman: Isu dan cabaran dalam konteks pembangunan pelancongan. Jurnal Melayu, 2.

Jabatan Perangkaan Malaysia (2019). Buletin Perangkaan Sosial.

Jabatan Perangkaan Malaysia (2010). Taburan Penduduk Mengikut Kawasan Pihak Berkuasa Tempatan dan Mukim, Pulau Pinang 2010.

Kalsom Kayat \& Nor Ashikin Moh Nor (2005). Penglibatan ahli komuniti dalam program pembangunan komuniti: Program homestay di Kedah. Akademika, 2005, 67, 75-100.

Kayat K (2009) Community based tourism in developing countries. Paper presented at the International Seminar on Community Based Tourism, Shah Alam, Malaysia, 4-5 August.

Kim, K. 2002. The Effects of Tourism Impacts upon Quality of Life of Residents in the Community. Ph.D Thesis, Faculty of the Virginia Polytechnic Institute and State University. Blacksburg, Virginia.

Kim, K., Uysal, M., \& Sirgy, M. J. 2013. How does tourism in a community impact the quality of life of community residents? Tourism Management 36: 527-540.

Konting, M. M. (2005). Kaedah Penyelidikan Pendidikan. Dewan Bahasa dan Pustaka.

Krejcie, R. V., \& Morgan, D. W. (1970). Determining sample size for research activities. Educational and psychological measurement, 30(3), 607-610.

Mendenhall, W., Beaver, R. J., \& Beaver, B. M. (2012). Introduction to probability and statistics. Cengage Learning.

Moscardo, G. 2009. Tourism and quality of life: towards a more critical approach. Tourism and Hospitality Research 9(2): 159-170. 
Mowforth, M. \& Munt, I. 2003. Tourism and Sustainability. Development and New Tourism in the Third World. London: Routledge Publishing.

Nordin, N. S., \& Ahmad, H. (2020). Pemetaan Aset dan Penglibatan Komuniti dalam Pelancongan di Kilim dan Makam Mahsuri, Langkawi. Jurnal Wacana Sarjana, 4(2), 1-13.

Noor, H. M., Zainol, R. M., Ling, N. G., Mapjabil, J., Ismail, R., Ab Rahman, B., \& Kumalah, M. J. (2017). Faktor budaya dan bukan budaya dalam mempengaruhi lawatan ulangan: Kajian kes pelancong asing Pulau Pinang (Cultural and non-cultural factors influencing repeat visits: A case study of Penang's foreign tourists). Geografia-Malaysian Journal of Society and Space, 11(12).

Peterson, M., \& Malhotra, N. (2000). Country segmentation based on objective quality-of-life measures. International Marketing Review, 17(1), 56-73.

Puczko, L., \& Smith, M. (2001). Tourism specific quality of life index: The Budapest model. Dlm. Quality of Life Community Indicators for Parks, Recreation and Tourism, disunting oleh M. Budruk \& R. Phillips. Springer.

Ridho, T. K. (2016). The Influence of CSR on Performance and Its Determinants in Listed Companies in Indonesia, (10), 259-268.

Ruzanna Syamimi Ramli, New Gaik Ling, Jabil Mapjabil, Mohamad Pirdaus Yusoh (2011) Faktor yang mempengaruhi kunjungan ulangan pelancong antarabangsa: Suatu tinjauan awal. Prosiding Persidangan Kebangsaan Ekonomi Malaysia Ke-VI 2011. Jilid II. Everly Resort Hotel, Melaka. 5-7 Jun.

Samad, S., Shukor, M. S., \& Mohd Salleh, N. H. (Eds.). (2013). Impak Pembangunan Industri Perlancongan Kepada Komuniti di Pulau Langkawi: Vol. PROSIDING PERKEM VIII, JILID 1 (Issue (2013) 207-216). Universiti Kebangsaan Malaysia.

Salleh, N. H. M. (2014). Sustainable Livelihood and Community Perception of Tourism Development: A Case Study of Langkawi Island, Malaysia. Semantic Scholar.

Salleh, N. H. M., Shukor, M. S., \& Idris, S. H. M. (2017). Impak Pembangunan Pelancongan ke atas Persekitaran Manusia dan Fizikal Komuniti Pulau Tioman (The Impact of Tourism Development on Humanity and Physical Environment of Pulau Tioman Community). Akademika, 87(3).

Sekaran, U. (1992). Research Methods for Business: A Skill-Building Approach (2 ed.). New York: John Willey \& Sons

Shudie, N. F. B., \& Gani, N. (2020). Impak Industri Pelancongan Terhadap Penduduk Kampung Tellian Tengah, Mukah, Sarawak: Satu Kajian Awal. Trends in Undergraduate Research, 3(2), H16-21

Shukor, M. S., Salleh, N. H. M., Othman, R., \& Idris, S. H. M. 2014. Perception of homestay operators towards homestay development in Malaysia. Jurnal Pengurusan 42: 3-17

Unit Perancang Ekonomi (1999). Laporan Kualiti Hidup Malaysia 1999. Jabatan Perdana Menteri. Dicapai pada Oktober 1, 2010.

Yu, C-P., Chancellor, H. C. \& Cole, S. T. 2011. Examining the effects of tourism impacts on resident quality of life: Evidence from rural Midwestern Communities in USA. International Journal of Tourism Sciences 11(2): 161-186.

Yussof, I., Omar, M., \& Saat, G. (2017). Impak Pembangunan Langkawi Ke Atas Corak Pekerjaan Dan Guna Tenaga Di Pulau Dayang Bunting, Langkawi (The Impact of Langkawi Development on Occupation and Employment Patterns in Pulau Dayang Bunting, Langkawi). e-Bangi, 4(1). 